\title{
Habermas and Ratzinger on the Future of Religion
}

Michael Welker

Universität Heidelberg, Kisselgasse 1, 69117 Heidelberg, Germany

mw@uni-hd.de

\section{Abstract}

The article investigates the encounter between Joseph Cardinal Ratzinger and Jürgen Habermas in Munich 2004. The event was widely regarded as a conversation about the topic 'The Pre-Political Moral Foundations of a Liberal State'. It was praised as a dialogue between the 'personification of the Catholic faith' and 'the personification of liberal, individual and secular thought' with far-reaching consequences. A close analysis of the texts, however, shows that Ratzinger and Habermas think in quite incompatible frameworks with very different concerns. They both share a sceptical attitude towards scientific ideology and they both show a remarkable lack of cultural and political realism. Habermas assumes that civil-societal elites will transform moral concerns into political and legal power. Ratzinger hopes for a revival of natural law tradition which would overcome the 'pathologies of reason' and political and religious fanaticism.

On 19 January 2004, a conversation took place between the philosopher Jürgen Habermas and the former prefect of the Congregation for the Doctrine of the Faith, Joseph Cardinal Ratzinger (now Pope Benedict XVI), at the Catholic Academy of Bavaria in Munich. The topic they had agreed to discuss was 'The Pre-Political Moral Foundations of a Liberal State'. Although the conversation itself was not published, the two lectures preceding the event were published by Florian Schuller, a priest educated at the Pontifical Gregorian University in Rome and director of the Catholic Academy of Bavaria, as The Dialectics of Secularization: On Reason and Religion. ${ }^{1}$ In the preface Schuller is obviously proud of having successfully 'brought together two persons who each represent entire intellectual, cultural and spiritual worlds' (p. 11). He promises 'exciting reading', commenting that 'one can hardly imagine two more fascinating dialogue partners to reflect on the basic questions of human existence' (pp. 13 and 11). Boldly he asserts that

1 Jürgen Habermas and Joseph Ratzinger (Pope Benedict XVI), Dialektik der Säkularisierung: Über Vernunft and Religion (Freiburg: Herder 2005). English edn: The Dialectics of Secularization: On Reason and Religion, trans. Brian McNeil (San Francisco: Ignatius Press, 2006). The page citations given in parentheses refer to the German edn. All quotations have been rendered in English by the translator of this article, Jennifer Adams-Massmann. 
Ratzinger is the 'personification of the Catholic faith', while in Habermas he sees 'the personification of liberal, individual and secular thought' (p. 12). In both he sees no less than the 'prototypes of a decisive dialogue in our day which will shape the future of our world' (p. 14).

The Bavarian Academy director accords worldwide intellectual significance to the conversation between them, claiming this debate has already had a 'precursor' in France, Italy and Germany. In fact, both Ratzinger and Schuller felt the public debate 'about the truth of the Christian religion' had been characterised by more intellectual passion in France and Italy than in Germany. Meanwhile, the German philosopher Jürgen Habermas delivered an acceptance speech for the peace prize of the German Booksellers, in Frankfurt in October 2001 (a month after the terrorist attacks on the World Trade Center in New York), which was seen by some commentators as 'laying the groundwork' for the churches. In his speech entitled 'Faith and Knowledge', Habermas warns against a 'derailing secularization' and suggests that enlightened common sense should be willing to learn from both science and religion.

Following an approach strongly reminiscent of Kant's Religion within the Limits of Reason Alone, ${ }^{2}$ Habermas argues in this speech that secular society risks cutting itself off from 'important resources for creating meaning' if it does not 'retain a feeling for the expressive power of religious language'. ${ }^{3}$ In keeping with Kant's and Hegel's Aufhebung of religious content in both senses Aufhebung as 'sublation' but also as 'maintenance' - Habermas advised the citizens of the liberal state to consider the religious source of the state's moral foundations in order to recover what he calls 'the expressive level of one's own history of origins'. He praises Kant for his 'secularizing but redeeming deconstruction of faith-truths' and for his 'critical adaptation of religious content', whatever that may mean.

Habermas is driven not just by anxiety about the kind of religious and post-religious speechlessness capable of driving peoples and cultures to embrace terror or self-trivialisation. He is also concerned about efforts to nurture the religious and moral foundations of the modern liberal state. He warns against a naturalistic-scientistic ideology which seeks to explain and describe everything scientifically, reducing personal and social human existence to nothing more than a natural process. The accompanying

${ }^{2}$ German original: Works, ed. Weischedel, vol. 8 (Königsberg, 1793). English trans.: Religion within the Limits of Reason Alone (New York: Harper Perennial, 1960)

3 www.glasnost.de/docs01/011014habermas.html. The following quotations have been translated from this speech which was given in German. 
'unsound philosophy' ought to be enlightened, not just by philosophy and science but also religion, according to Habermas.

Reflecting on the subjects of 'sin', 'resurrection' and 'the human as imago dei' in a vague way, Habermas considers the loss of concrete religious content, writing that when 'sin turned into guilt, something was lost', and that the 'lost hope of resurrection leaves behind a noticeable emptiness' ${ }^{4}$ He argues that the "creaturely aspect of the imago dei expresses an intuition that can even address our own context of religious un-musicality'. Against this backdrop Habermas suggests a 'reasonable approach' which seeks 'to keep its distance from religion without completely closing itself off from its perspective'.

Even if such reflections cannot truly be described as 'laying the groundwork' for the church, Habermas is clearly contradicting the widespread view of religion shaped by aspects of the European Enlightenment and subsequent, related ideologies which see religion as nothing more than superstition. According to this perspective, some aspects of religion may be worth keeping in museums, but the rest belongs on the rubbish heap of cultural history along with all the other 'delusions and confusions' of humanity. Habermas' advice, on the other hand, follows in the tradition of Kant and Hegel by seeking to learn from religion's potential for knowledge and language, albeit in a reserved and still secularising manner. Certainly Kant and Hegel's agendas must be appreciated as historically successful attempts to turn the formative power of the Christian religion into processes of moral formation and liberation. At the same time, evidence suggests that their transformative critique of religion evoked stronger and more enduring trends towards secularisation - at least in parts of Europe - than the more aggressive forms of denunciatory critique of religion associated with Feuerbach, Marx and Nietzsche. Although such campaigns of transformative critique of religion have powerfully influenced culture in global history, trust in their validity has largely eroded since then. The mass media today overwhelmingly show us numerous examples of the 'sublation' of religious forms and content, yet it is hard to discern much more in these than the profanation and degradation of religion in order to amuse, confuse, shock and dismay.

${ }^{4}$ Cf. on these subjects: Sigrid Brandt et al. (eds), Sünde: Ein unverständlich gewordenes Thema (Sin: A Topic that has Become Incomprehensible), 2nd edn (Neukirchener: NeukirchenVluy, 2005); Hans-Joachim Eckstein and Michael Welker (eds), Die Wirklichkeit der Auferstehung (The Reality of Resurrection), 3rd edn (Neukirchener: Neukirchen Vluyn, 2007); Ted Peters, Robert Russell, and Michael Welker (eds), Resurrection: Theological and Scientific Assessments (Grand Rapids, MI: Eerdmans, 2002); 'Menschenwürde' (Human Dignity), Jahrbuch für Biblische Theologie 15 (2001), esp. pp. $247 \mathrm{ff}$. 
Nonetheless the question remains: why do almost 80 per cent of people on the globe today express a religious affiliation? In fact, this religious trend is globally increasing quantitatively rather than declining if we consider developments in China. And this despite the promise that the twentieth century would usher in the so-called scientific and technological 'disenchantment of the world'! Moreover, the twentieth century began by dealing particularly with the crimes of Christianity in global colonialism and cultural imperialism. It brought us the Marxist battle against religion in the double strategy of enlightenment and repression as well as intense criticism of the spread of patriarchal ideologies in many religions. Finally, we were forced to witness the horrifying fusion of religiosity and suicidal, murderous terrorism along with the fundamentalist glorification of militaristic, hegemonic policies. Indeed, at the end of the twentieth and beginning of the twentyfirst centuries, practised religiosity is suffering from a widespread, lingering illness, especially in western and central Europe and Australia, in the forms of self-secularisation and self-trivialisation. We see reductionist theisms, as expressed in the formula 'God is the all-determining reality', meshed together with diffuse searches for meaning, symbolic kitsch, the cult of health, media piety and other signs of decline and disintegration.

In the midst of this many people hold surprisingly fast to religious traditions. They evince a sometimes passionate - or merely obstinate -interest in old and new forms of spirituality, religiosity and scientifically orientated faith. Additionally, in the growth of the Pentecostal churches and charismatic groups we are experiencing the largest 'piety' movement in human history. We are further witnessing a process of re-Christianisation in many formerly communist and atheist countries. In Africa, Asia and Latin America massive religious developments and regroupings display an intense religious energy and strong interest in religious life. Particularly interesting for academic theological observers at present are strong Christianising developments in China and India. Yet, in his dialogue with Ratzinger, Habermas' inquiry into the 'pre-political foundations of a democratic constitutional state' focuses above all on European and American contexts.

Let us consider this for a moment. As in his Frankfurt speech, Habermas is trying in this dialogue to prevent secularisation from being 'derailed'. On the one hand, he advises his contemporaries - including even those who are 'religiously unmusical' as he considers himself - to engage in dialogue with religion since it has not gone away (at least 'for the time being', in his opinion). On the other hand, he advises his contemporaries to participate in the Aufhebung of religion in the Hegelian double meaning of the word by transposing relevant religious contributions and language into generally accessible language. 


\section{Pre-political foundations of a democratic constitutional state?}

In 1968 an article by the constitutional judge Ernst-Wolfgang Böckenförde appeared in the Festschrift for E. Fortsthof entitled, 'The Emergence of the State as a Process of Secularization'. One sentence in the article could probably end up in the Guinness Book of World Records as the most frequently quoted jurisprudential statement of the twentieth century. Indeed, Böckenförde's statement was probably one underlying reason for the dialogue between Habermas and Ratzinger, and Habermas expressly refers back to it. The statement is as follows: "The liberal secularized state exists based on presuppositions it cannot guarantee. ${ }^{5}$ Habermas wonders whether this liberal secularised state is actually dependent on 'traditions specific to one particular worldview, locality or religion or, at any rate, on collectivelybinding ethical traditions' (p. 16).

He claims that the secular, ideologically neutral state is legitimated by secular, philosophical sources from the seventeenth and eighteenth centuries (cf. p. 18). In order to understand this one need not assume that government has to be domesticated by religion or other means. The emphasis lies instead on the current social reality of the 'democratic process' in which we can perceive the 'inclusive and discursive process of opinion formation and decision-making' by associate citizens. This process requires only 'weak presuppositions about the normative content of the communicative nature of socio-cultural forms of life' (p. 19). According to Habermas, these weak presuppositions are satisfied when the democratic process establishes an assumption that the results of communication about the foundations of lifestyles are rationally acceptable - even to the point that they could constitute constitutional principles. On this basis the legal regulation of state authority, continuously underwritten by loyalty, can take place. A stable power arrangement is thereby in place that does not require any higher 'maintaining power' of a religious or other nature.

That Habermas' project has been strongly influenced by Immanuel Kant becomes clear when Habermas distinguishes between 'citizens of the state who understand themselves as authors of the law', and 'citizens of society who are addressees of the law' (p. 22). The democratic process Habermas has in mind is apparently designed to help the "citizens of society concerned with their own well-being' to see themselves more and more as 'citizens of the state' and behave accordingly. These citizens, conscious of their power as authors of the law, would continually strengthen the "uniting bond of

${ }^{5}$ Ernst-Wolfgang Böckenförde, 'Die Entstehung des Staates als Vorgang der Säkularisierung', in Böckenförde, Recht, Staat, Freiheit. Studien zur Rechtsphilosophie, Staatstheorie and Verfassungsgeschichte (Frankfurt: Suhrkamp, 1991), pp. 92-114, 112. 
the democratic process'. Or, to be more precise: by competing for the best interpretation of controversial constitutional principles, they would keep this process alive, only accepting rational procedures. Habermas concedes that this demanding process has what he calls 'pre-political' historical sources: a common religious background, a common language and a continually reawakened national consciousness (cf. p. 24). He considers cultural-political evolution to be forceful enough to offset, liquefy and possibly make superfluous some of these sources in the discursive and democratic powersharing arrangement.

Habermas affirms a self-critical 'politics of memory' and a 'constitutional patriotism' which value and constantly reappraise constitutional principles discursively in the contemporary context. Just as Immanuel Kant saw the coming of the kingdom of God on earth in faithful obedience to the categorical imperative, so Jürgen Habermas sees the emergence of an ever-stronger solidarity of 'citizens of the state' through a 'democratic process'. This is sustained by a self-critical politics of memory, constitutional patriotism, the juridification of the state and an insistence that political processes be rational. These 'citizens of the state', as selfconfident authors of the law, increasingly provide access to the "principles of justice in the dense network of ethical orientations in a culture' (p. 25).

In Habermas' vision of a process in which more and more 'citizens of society' are transformed into 'citizens of the state', we see Kant's theory of autonomy being transposed into a sphere shaped by civil society and sociality. These citizens of the state understand themselves more and more as authors of the law, and increasingly better and clearer principles of justice are anchored and legalised discursively and institutionally in a network of cultural value-orientations. Habermas is aware of how profoundly illusory this vision may be and reflects on this danger in a section entitled: 'When the social bond breaks ...' (p. 26).

Above all it is the power of the market and especially the "politically uncontrollable dynamics of the global economy and society' (p. 26) which cause Habermas to fear a 'derailment of modernization' and erosion of civil society's solidarity. In his extensive preface to the most recent edition of his classical book, The Structural Transformation of the Public Sphere (1990) and in the book Between Facts and Norms (1996), Habermas vividly describes the danger that the forces of civil society, including the democratic process, will be distorted and misled through interaction with the electronic mass media. The mass media exercise power over the public sphere by choosing or repressing subjects for presentation and by generating the illusion of communication and participation. These media shape society and contribute to the lowering 
of the 'discursive level'. 6 Habermas speaks dramatically of 'arenas where power is exercised' in civil society. The media 'hide their intentions while struggling to control the flow of communication, thus maximizing their influence on behavior' ${ }^{7}$ He sums up the situation with some scepticism in Between Facts and Norms:

The sociology of mass communications certainly conveys a skeptical image of the public sphere of western democracies dominated by mass media (as reduced to a mere power struggle). Many groupings in civil society are indeed sensitive to problems. Yet when they express their concerns, their signals and impulses are generally too weak to catalyze short-term learning processes or redirect political decision-making processes. ${ }^{8}$

In my opinion, Habermas adopts a more down-to-earth and realistic view of things in this earlier work, conceding that the associations in civil society (including the 'democratic process') are not 'the most conspicuous elements of a public sphere dominated by the mass media and major agencies, observed and analyzed by marketing and public opinion research groups, and steeped in public relations, propaganda and advertising by political parties and organizations'. 9

In the article drafted for his dialogue with Ratzinger, however, Habermas freely adopts a different approach. Here he warns against interpreting the crises and hazards of the democratic process in terms of a critique of modern reason, thereby robbing itself of its own foundations for development and awakening great expectations for the redemptive potential of religious discourse. Explicitly distancing himself from cultural critics such as Martin Heidegger, Carl Schmitt and Leo Strauss, he argues:

I think it is better not to get carried away with a critique of reason when answering the question whether an ambivalent modernity can stabilize

${ }^{6}$ Jürgen Habermas, Strukturwandel der Öffentlichkeit: Untersuchungen zu einer Kategorie der bürgerlichen Gesellschaft. Mit einem Vorwort zur Neuauflage (Suhrkamp: Frankfurt, 1990), pp. $27 \mathrm{ff.}$ English edn: The Structural Transformation of the Public Sphere: An Inquiry into a Category of Bourgeois Society (Studies in Contemporary German Social Thought) (Cambridge, MA: MIT Press, 1991).

7 Ibid., p. 28; cf. idem, Faktizität and Geltung: Beiträge zur Diskurstheorie des Rechts and des demokratischen Rechtsstaats (Suhrkamp: Frankfurt a.M., 1992), pp. 444-5, and in other places. English edn: Between Facts and Norms: Contributions to a Discourse Theory of Law and Democracy, trans. William Rehg (Cambridge, MA: MIT Press, 1996). English trans. in this text by H. A.-M.

${ }^{8}$ Faktizität and Geltung, p. 451; cf. M. Welker, Kirche im Pluralismus, 2nd edn (Kaiser: Gütersloh, 2000), ch. 1.

9 Faktizität and Geltung, p. 444. 
itself using only the secular forces of communicative rationality. Let us regard it instead as an open, empirical question. (p. 28)

Yet he does not try to examine these issues empirically by reflecting on the opportunities and dangers of his discourse about justice in civil society within the power structure of pluralistic societies (including the religions still existing within them). Instead, he offers an 'excursus' on the religious and metaphysical origins of philosophy.

At the end of an impressive philosophical overview extending from Aristotle's Metaphysics book 12 to the epigones of Fichte, Hegel and Schleiermacher, Habermas speculates that self-reflective reason 'discovers its origins "in another" whose fateful power it must acknowledge' (p. 29). This understanding of self-reflective reason could be seen as an extension of Schleiermacher's 'self-consciousness of the knowing and acting subject' or Kierkegaard's view of 'the existential historicity of one's own selfreassurance' or the Hegelian and the Left Hegelian understanding of 'the provocative disruption of moral relationships'. Although its origins are not theological, a form of self-reflective reason that is both aware of and transcends its own limits can easily be absorbed into theology. It then transcends itself towards 'mystic fusion with a consciousness encompassing the universe' or 'in the desperate hope for the historical appearance of a redeeming message' or 'a solidarity with the oppressed and persecuted which asserts itself and seeks to speed up the messianic salvation' (p. 29).

Habermas sees his original construction of a rationality with a three-fold orientation to 'its otherness' as nothing less than the 'deciphering of the pseudonym of the Trinity of the self-communicating personal God' (p. 30). And he remarks - in his own favour - that adopting such philosophical theologising from Hegel is 'still more congenial' than a prophetic gesture in the style of Nietzsche's irate criticism of Christianity, metaphysics and morality. Along with his philosophical contribution to the theory of the Trinity, Habermas presents his own position and the philosophical approach he recommends as more open to learning when compared to Kant and Hegel. For one thing, 'respect for persons and lifestyles that clearly acquire their integrity and authenticity from religious convictions' (p. 30) requires refraining from using philosophy to demonstrate superior cognitive judgement in religious matters. Furthermore, given past experiences with socio-cultural developments and the need to plan for future forms of societal coexistence, it is necessary to apply continuously a reciprocal process of learning between philosophy and religion. With this advice Habermas perhaps goes a step beyond the recommendations in his peace prize speech that one should 'maintain a distance from religion without completely 
closing oneself off from its perspective'. It remains unclear, however, whether this only means attempting to observe and translate selected religious statements (all the while hoping religion will go away), or whether Habermas is able to take a real, constructive interest in the development of religion as a valid dialogue partner and an object of observation in its own right.

While Habermas in the peace prize speech tentatively and vaguely addressed religion's 'important resources for making meaning' and the 'expressive power of religious language', in his dialogue with Ratzinger this approach becomes clearer. So long as it avoids dogmatism and does not coerce people's consciences, religion is endowed with an important spiritual immune system beyond that of mere ethical, ascetic, post-metaphysical systems of thought. It possesses 'adequate sensitivity and differentiated ways to express the reality of ruined lives, societal pathologies, the failure to realize individual life plans, and the distortion of life's coherence' (p. 31). Furthermore, throughout its developmental history Western philosophy has transformed 'genuine Christian ideas ... into dense normative conceptual networks'. Habermas uses, let's say, an 'elevated language' to speak of 'saving' (or perhaps 'salvaging') translations of religious content by philosophy. Translating the imago dei into the 'equal dignity of all people who deserve unconditional respect' is his prime example of such a 'saving translation' (p. 32).

He emphatically recommends that all citizens of 'post-secular society' as well as state constitutional authorities 'deal carefully with the cultural wellsprings which feed into the consciousness of norms and the solidarity of all citizens' (pp. 32-3). It is quite evident that, in his view, philosophically articulated and cultivated forms of religiosity and secular thinking should learn mutually from one another, serving to protect and strengthen social solidarity. This solidarity should be nourished through the democratic process to resist the power of the market and seemingly value-neutral governments. Furthermore, Habermas contends that the democratic process will inexorably have a secularising tendency which unfolds in stages: 'for now we must reckon with the continued existence of religious communities; the processes of modernization do not engage with religious and secular mentalities all at once but in phases' (p. 33). With Habermas' philosophicalreligious contribution to dialogue - focused on the German and Western European contexts and 'open to learning' - we sense Kant and Hegel calmly peering over their shoulders at their philosophical great-grandson.

At the end of his reflections Habermas tosses out an interesting question. Given the modern 'differentiation of the societal substructure', religion and politics distinguish between the roles of church members and those of citizens of society. Yet how should politics (and the various actors in civil society's 'democratic process') deal with those engaged religious adherents 
whose political loyalty and conscious participation in the discourse of justice are not guaranteed if this means compromising their religious commitments? The first answer is this: they should practise tolerance and allow for religious configurations to take shape in the secular sphere. The second answer is more specific: tolerance should not be confused with a laissez-faire attitude. It comes at a price, as shown by the public uproar and fierce conflicts unleashed by liberalised abortion regulations. The third answer adds to that: one can no longer automatically assume that religion is irrational (even if this assumption is never voiced). And one can no longer grant 'extra credit for rationality' to ideologically susceptible worldviews, such as scientistic naturalism, merely on the grounds that such perspectives do not derive from traditionally religious premises but supposedly originate in the scientific system. Habermas gently suggests that interesting debates may ensue between religious truth-claims and claims based on secular, scientific premises, in which the more intellectually sophisticated 'citizens of the state' could take part rather than acting as passive observers only. Like Habermas ${ }^{10}$ (and Kant before him), these citizens should definitely 'participate in the struggle to translate relevant contributions from a religious mode of expression into a publicly accessible language' (p. 36).

\section{'What holds the world together': the pre-political moral foundations of a liberal state}

Jürgen Habermas seeks to promote the survival and further development of the liberal state and society, whereby what is primary is civil society's process of communication, especially the role of the 'citizens of the state', who need to be aware of their task. The citizens of the state, who view themselves as 'authors of the law', are apparently expected to perform miracles through the 'democratic process'. They are expected to prop up and strengthen law, politics, science, education and the family against the forces of the market, the media and scientistic ideologies - all with help from the classical religions.

Joseph Cardinal Ratzinger, in his article introducing his discussion with Habermas, does not view the problem in the same way. Without Habermas' concern about the global market (2004) and even greater anxiety about the power of the media (from 1990), Ratzinger can speak calmly about the current formation of a world society with multiple and mutual interdependencies. He is concerned, however, about 'the development of possibilities for humans to create and destroy, exercising a power beyond

10 Not only in his speech accepting the peace prize of the German Publishers and Book Sellers Association, but also in Habermas, Glauben and Wissen (Suhrkamp: Frankfurt, 2001). 
anything known so far and raising questions about legal and ethical controls on power' (p. 40). From the outset he perceives 'legally accountable forms of restraining and organizing power' (p. 40) as an intercultural problem. For this reason, the important quest for the 'ethical foundations' which 'lead the coexistence (of cultures) in the right direction' cannot be entrusted solely to discourse groups within society.

In addition to this global perspective, Ratzinger expresses an ethical scepticism. 'In the process of cultural encounter and mutual penetration', the traditional, fundamental 'ethical certainties have largely disintegrated'; and the question of 'what is the good, and why one must do it, even to one's own detriment', remains 'largely' unanswered (p. 40). The abandonment of tradition, a lack of moral orientation and an unwillingness to make sacrifices all pose grave problems.

The relativising of traditional ethical certainties through multicultural interference is only one of the central problems Ratzinger names. In addition, the growing body of multidisciplinary scientific knowledge reflected in changing images of humanity and the world is, in his view, also partly responsible for the 'destruction of old moral certainties' (p. 41, cf. ibid.). In his opinion, this situation requires that philosophy serve as a dialogue partner for science, religion and the church by critically challenging alleged scientific advances, helping to weed out pseudo-scientific and non-scientific ideas. With the help of philosophy Ratzinger wants to keep the 'focus on the larger picture, remaining open to further dimensions of the reality of human existence' (p. 41). One must carefully consider which philosophy would be in a position to take this responsibility seriously as part of the scientific research process. Which philosophy could serve as a critical companion for scientific evolution and focus 'on the larger picture, remaining open to further dimensions of the reality of human existence'? One must also remember the well-founded criticism of the great Swiss theologian, Karl Barth, who said that idealistic, existentialist, naturalist and other philosophies only apprehend certain (selected) 'phenomena of humanity' but never perceive the real and genuine human being. ${ }^{11}$

After determining the role of philosophy in the evolution of the sciences (a subject worthy of further discussion), Ratzinger turns to the task of politics. He formulates it well and succinctly: "Not the law of the strong but the strength of the law must rule'. Politics is therefore accorded the task of placing 'power under the criterion of the law', making 'jointly-shared freedom' possible (p. 42). At this juncture Ratzinger's and Habermas' approaches come closer together even as they maintain a careful distance. According

11 Karl Barth, Kirchliche Dogmatik (Church Dogmatics), III/2, para. 44.2. 
to Ratzinger, the law must be the 'vehicle of justice' and 'expression of the common interest shared by all'. This militates in favour of democracy 'as the most appropriate form of political order' (pp. 42 and 43). At the same time, 'the tools of democratic decision-making' solve the problems associated with democracy at least 'for now' (pp. 42-3). The fact that majorities and democratically elected delegations are corruptible necessitates the question whether there are injustices which can never be made right and whether there are inalienable laws no majority is able to abrogate (cf. p. 43).

In modern declarations of rights Ratzinger sees an attempt to secure the foundations of the law. As an indication of the very diverse levels of acceptance these human rights have been accorded in various cultures in the world, he writes:

the contemporary mindset is certainly satisfied with the inherent obviousness of these values. But even such self-limitation in asking the question has a certain philosophical character. There are inherent values which result from the nature of being human and therefore are inalienable for all those who possess this nature. (pp. 43-4)

If I am interpreting these sentences correctly, then the task and competence of philosophy in the political and legal domain is to 'focus on the larger picture, remaining open to further dimensions of the reality of human existence' and to identify consensus as provisional and relative. Philosophy must grow beyond the current state of knowledge and identify non-relative values which arise from the 'nature of being human'.

With his affirmation of democracy and human rights from a cosmopolitan perspective, Ratzinger positions himself in a tradition of papal thought and judgement which brings to mind the Christmas messages of Pius XII in 1942 (The Internal Order of States and Peoples) and 1944 (Democracy and a Lasting Peace). ${ }^{12}$ In response to the atrocities of National Socialism the Pope in 1942 emphasised the meaning of human dignity and basic human rights, while in 1944 he stressed the necessity of establishing international organisations promoting peace. In his 1963 encyclical Pacem in Terris John XXIII expressly referred to the human rights affirmation of 1942 and paved the way for the human rights policy of the Second Vatican Council's constitution supported by the UN. This emphasis was especially clear in the text Gaudium et Spes of 1965. Paul VI and John Paul II continued to follow this cosmopolitan line of argument in

12 In this paragraph I have benefited from a text by my Harvard colleague Francis Fiorenza, which has not yet been published: 'Freedom and Human Rights: The Cosmopolitan Context of the Justification of Rights in Roman Catholicism', 2007. 
their own official statements, while John Paul II also insisted on the necessity of embedding human rights in national legal systems.

In the section subtitled 'New Forms of Power and New Questions about How to Deal With it' (p. 45), Ratzinger takes a look back over the years since the Second World War and identifies a shift in terms of 'the issue of justice and an ethos'. The fear of mutual nuclear destruction by the world's superpowers has been displaced by the fear of 'the anonymous forces of terror that may be present anywhere' (p. 46). Ratzinger enquires which sources feed into terror. He names, for one, the feeling of powerlessness and the hatred felt by 'powerless and oppressed peoples' who consider terror a 'response ... to the arrogance of the powerful, as just punishment for their blasphemous selfglorification and cruelty'. He also names a form of religious fanaticism which presents terror 'as a defense of religious tradition against the godlessness of Western society' (p. 46). In his opinion this requires religion to adopt a self-reflective and self-critical attitude. What conditions cause religion to display either a 'healing and saving' power or an 'archaic and dangerous' one (pp. 46-7)? Is it possible to develop a reasonable process to purify and contain religion within certain boundaries - and if so, who could accomplish this? Or is a gradual abolition of religion desirable in order to achieve cultural progress towards 'freedom and universal tolerance'?

Ratzinger warns against an unqualified faith in the potential of 'reason', which also served to produce the atomic bomb and 'the breeding and selection of human beings', as he calls it. Borrowing from the Cold War model in which 'the mutual limitation of power and the fear for one's own survival ... [proved to be] the saving forces' (p. 45), he recommends that religion and reason mutually limit each other. They should mutually 'reign in and help one another to get on the right path toward their own positive goals' (p. 48). Such a mutual setting of limits would have to be implemented in all societies. Yet where are the forces of motivation and enforcement to be found? Who would be able to convince the people, the political authorities and last (but not least) science and religion of the necessity and practicability of such a project?

Ratzinger's answer to this urgent question sounds cautious if not uncertain. 'Natural law' has remained within the Catholic Church 'the model for argumentation which the church uses in discussions with secular society and other faith communities to appeal to common reason and in the search for a foundation to agree on the ethical principles of the law in a secular, pluralistic society' (p. 50). Regretfully he observes, however, that 'this tool has lost its effectiveness unfortunately, so I prefer not to rely on it for this discussion' (ibid.). He holds that human rights 'are the last elements of natural law ... still remaining', in other words, only human rights can 
still be used in argumentation as they continue to be relevant. He calls for the retrieval of those values and norms inherent to human existence and which cannot be considered mere inventions. He calls for philosophy and a Christian theology of creation to join in the search for sustainable foundations for natural law inherent to human existence. At the same time, he challenges the other major religious traditions of the world to take part in this project.

His contribution concludes with a meditation on 'intercultural dynamics and their consequences'. Ratzinger speaks about five 'cultural spheres', namely Christianity, Islam, Buddhism and Hinduism as well as tribal religions. All of these cultural spheres are shaped by tensions. In the Christian sphere he senses tension between Christian faith and secular rationality. Could a fruitful relationship emerge from this tension which, as he puts it, would promote mutual 'purification and healing'? Ratzinger freely admits that 'pathologies in religion' exist which require the healing power of reason, then quickly moves on to address what he views as the more menacing (at least in terms of their effects) 'pathologies of reason'. Because of these pathologies, secular reason must learn to 'listen' to the great religious traditions of humanity. He envisions a 'polyphonous correlation' in which the various major religions would achieve constructive and peaceful relationships with secular rationality and in this way engage in mutual dialogue. In this event the fundamentals of natural law would be recognisable in a new way so that the 'essential values and norms which are known or sensed by all people could attain a new luminosity' (p. 58).

\section{Habermas and Ratzinger - a real conversation with one another?}

At a very general level of observation we could view the contributions of Habermas and Ratzinger as a 'dialogue', as the Bavarian Academy Director Schuller and the publishing house publicists claim. Ratzinger, the theologian and church leader, seeks dialogue with philosophy and seeks to employ its services as a critical companion to the sciences. He also seeks its services in order to discover or rediscover normative foundations 'in the nature of human existence', foundations which are 'immovable' and cannot be relativised. Habermas, philosopher and diviner of the Zeitgeist, on the other hand, recommends engaging in dialogue and listening to religion so that its insights can be incorporated into the 'normative content of the communicative constitution of socio-cultural lifestyles' and translated into secular language.

Yet, as soon as we move beyond this superficial observation level, we must ask whether these two thinkers' positions can actually be brought into dialogue with one another and whether they share a common sense of the 
direction of progress or have comprehensible and clear points of agreement and disagreement. In fact, the more closely we consider it, we are no longer surprised that the conversation itself was not published or that Ratzinger remarked laconically to the press at the time that there had been 'some agreement in operational ways'.

Habermas concentrates on the so-called 'democratic process', on civil society and on the intra-societal communicative dimension, wanting to identify the 'pre-political moral foundations of a liberal state'. Meanwhile, Ratzinger has in mind a global, political, multicultural and multi-religious situation full of potential dangers, and he is seeking legal and moral controls or even the 'taming and ordering' of power. So his 'problem children' include an unleashed scientific-technological evolution, spreading moral relativism and fundamentalist and fanatical religious attitudes. Caring for and maintaining the 'pre-political moral foundations of the liberal state' is, at best, an indirect concern. Yes, the state should 'tame' the powers with help from the law. And yes, he certainly recognises the danger that even democratic regimes and societies can be corrupted. But he does not really consider carefully the democratic and communicative process, which creates a liberal order and allows for a just development of rights accompanied by political and moral public discourse.

Apparently the existence of this process is taken for granted, at least in some parts of the world. Clearly these two thinkers are preoccupied by very different concerns and problems in very different areas of observation.

A possible point of contact between their perspectives may be the common concern about scientism, a faith in the complete competence and self-sufficiency of modes of thinking derived from science, especially or exclusively natural science. This attitude might become ideologically entrenched and disguised in a critique of religion. The supposedly naive and now bygone era of religion serves this scientism as a useful contrast and foil in order to spread a contemporary, progressive faith in science's monopoly on the truth. Starting a conversation on this point, however, requires reappraising and changing basic attitudes on both sides.

What indeed needs to be reworked is Habermas' half-hearted strategy, which argues for the sublation of religion in the long run, yet grants a postponement of secularisation for the time being. He rightly senses that the theological doctrine of sin offers relevant religious insights for a critique of legal, moral and even systemic blindness. It can be shown that theological eschatology, and particularly the doctrine of the resurrection, is capable of fundamentally and correctly calling naturalistic ideologies into question. He suggests himself that the doctrine of humanity as made in the image of God lends support to radical democratic developments and problematises 
religious justifications of class societies and class churches. This and other potential benefits of religion for knowledge require continual interpretation and intellectual nurture, as well as further development under modified conditions in the sciences and various worldviews and a pedagogical medium capable of reaching broader segments of the public. One ought to decide from the outset whether merely to sublimate the Enlightenment's emptying and repression of religion or whether (wisely) to put an end it. This by no means precludes a continuing specific critique of religion in the wake of the Enlightenment, although religion would be embraced in principle. The best Protestant theologians of the twentieth century such as Barth, Bonhoeffer and Tillich were not wrong to incorporate a critique of religion into their theological agendas.

Ratzinger's proposal to engage with the evolution of the sciences and the 'pathologies of reason' is also in need of further development. Only a few philosophers would still share Ratzinger's view of a monolithic 'Reason', when they refer to historical contexts and the academic system. Even Hegel experts, publishing the results of a recent Hegel convention, chose to name the volume Concepts of Rationalities in Modernity (Vernunftbegriffe der Moderne). Replacing the term 'reason' with talk of 'rationalities' has contributed, among other things, to ending a cold war - in communist contexts really a 'hot' battle - between politics, science and religion. We cannot undo the distinction within the academic system by denying that the rationality continuum has been broken. Just as Ratzinger accepts the global differentiation into five cultural groupings conditioned by religion, he should not attribute differentiation in the sciences to the "pathologies of reason'. With the philosophical and theological observation of science and interdisciplinary dialogue in mind, we need a constellation which Ratzinger somewhat awkwardly calls 'polyphonous correlation' and which he hopes will deal with the critical correlation of philosophy and science.

I have already registered my misgivings about whether we even possess a philosophy capable of partnering with the various scientific disciplines in their evolution, and I share these misgivings on the basis of twenty years of more or less successful international and interdisciplinary research cooperation. My doubts extend even to the hope that only philosophy can reveal the normative foundations which theology and the church need for global inter-religious dialogue - foundations which would protect politics and law from moral relativism while dismantling scientistic and naturalistic ideologies.

I see a problem not only with Ratzinger's exaggerated and misguided belief in philosophy's potential, but also with his opinion that the tool of natural law has simply become dull but could be sharpened and rightly 
applied again. It would be cheap to try to argue that more or less desperate attempts in the post-war era to strengthen the traditions of natural law have again failed miserably, and one should not waste any more energy on this front. In fact, we are seeking sustainable equivalents to some of the concerns of natural law thought via a multi-year interdisciplinary and international research project 'Concepts of Law in the Natural Sciences, Jurisprudence and Theology', in which philosophy is also involved. My concerns are much more orientated towards some methodical and content-based distortions in Ratzinger's vision of a solution for many of the global problems he names.

The critical partnership he desires between 'reason and religion' cannot be produced alone in dialogue between theology and philosophy, and least of all by cultivating the suspicion that all science is scientism or even by demonising scientific rationality. On the contrary, exemplary issue-driven discourse with various scientific rationalities will be necessary for this partnership to thrive.

Ratzinger's desired concentration 'on the larger picture and on the further dimensions of the reality of being human' requires a multidisciplinary approach capable of bringing together perspectives from the natural sciences and the humanities. It also ought to be intentionally focused on substantive theological matters. If such a multidisciplinary approach is not embraced, there is a risk that the sought-after insights will not be accepted within the sciences and secular rationalities. Furthermore, there is also a real danger of religion losing its sense of direction in the end. After all, with natural law humans may ultimately be talking to themselves. Karl Barth famously identified this as a major threat for both Roman Catholicism as well as NeoProtestantism when they are devoid of theological content.

Interestingly, Habermas, the philosopher who calls himself 'religiously unmusical', seems to be more sensitive to this danger than the former cardinal and current Pope. Habermas, for example, warns against the loss of the concept of sin and mourns the loss of resurrection hope. Whatever the rationale, natural law concepts cannot guarantee us any genuine Christian theological foundations for knowledge. Therefore it is ultimately not a practicable basis for dialogue with the other major world religions. Should it be used here and there as the basis for dialogue, sooner or later it will be rejected again as a philosophically embellished relic of Western hegemonic thought. Ratzinger's desired 'polyphonous correlation' is considerably more sophisticated and time-consuming than he imagines, both in inter-religious dialogue and in dialogue with philosophical and scientific rationalities.

The goal Ratzinger seeks in his contribution, which is not satisfactorily developed, corresponds to an unsatisfactory initial constellation in Habermas' article. The efficacy and sustainability of his 'democratic process' in the power arrangement of structural pluralism in late-modern societies must 
be considerably more in touch with operational forms in politics, law and education. At the same time, its differences with the rationalities of the market and media should be more clearly delineated. Habermas ought not to fall short of the cognitive level he achieved in the early 1990s.

In the end it is good to know that Ratzinger is an extremely important but not the sole - 'personification of the Catholic faith' and that Habermas is a very instructive - but not the sole - 'personification of liberal, individual, secular thought' among us. It is also good to know that the intended and partially realised dialogue between them will not (thank God) 'determine the future shape of our world'. 